\title{
GAUCHOS E BÁRBAROS: A HISTÓRIA DA FORMAÇÃO DA NACIONALIDADE ARGENTINA A PARTIR DA LEITURA DE JORGE LUIS BORGES
}

\author{
Márcio Bobik Braga \\ Universidade de São Paulo
}

\begin{abstract}
Resumo: O presente artigo tem como objetivo mostrar que Borges convida o leitor a mergulhar, em alguns de seus textos, em uma complexa e instigante história acerca da formação da nacionalidade na Região do Prata durante o século XIX. Nessa história, podemos encontrar o debate entre duas visões que prevaleceram na literatura argentina na segunda metade do século retrasado: a "interpretação da barbárie", de Domingo Faustino Sarmiento, em seu Facundo o Civilización y Barbarie e a "denúncia da exploração", de José Hernández em seu poema El Gaucho Martin Fierro. Nesse debate, Borges procura caracterizar o gaucho, aquele que teria sido assimilado ou desaparecido no processo de consolidação da cidade de Buenos Aires como centro político e econômico da região. Podemos também encontrar um Borges contraditório. Se por um lado ele defende a civilização, por outro se vê fascinado pelo autêntico, por um ser não necessariamente civilizado. Estaria Borges preocupado em mostrar sua contradição? Essa talvez seja uma pergunta menor. Mais importante aqui é o método, o que une a história e a literatura.
\end{abstract}

Palavras-chave: Jorge Luis Borges. História da Argentina. História da América Latina

\section{Introdução}

Na edição de Facundo o Civilización y Barbarie, de 1974, obra do célebre romancista e político argentino Domingo Faustino Sarmiento e um dos principais textos da literatura latino-americana, Jorge Luis Borges, autor não menos célebre, escreveu um interessante e provocante prólogo em que afirma: "não direi que Facundo é o primeiro livro argentino; as afirmações categóricas não são caminhos de convicção, mas de polêmica. Direi 
que, se o tivéssemos canonizado como o nosso livro exemplar, outra seria a nossa história, e melhor" 1 .

Apesar de não citar o outro livro, Borges deixa mais do que explicito nesse e em outros textos e poemas que a canonização teria sido destinada ao El Gaucho Martín Fierro, concebido pelo periodista, político e escritor argentino José Hernández. Essa citação revela mais do que uma opção literária. Nela, o autor propõe, consciente ou não, a união de dois conceitos antagônicos que fizeram parte de um dos debates mais importantes sobre a formação da nacionalidade argentina durante o século XIX. Muitos interpretaram aquele momento como sendo o palco de um conflito entre a cidade e o campo, entre o porto de Buenos Aires e as províncias do interior da Argentina, entre diversos grupos políticos e sociais, entre a civilização e a barbárie. Teria também sido o período do desaparecimento de um tipo ou ser sul-americano: o gaucho. Todas essas questões foram tratadas por Sarmiento e por Hernández no século XIX e resgatadas por Borges em vários de seus textos.

$\mathrm{O}$ presente artigo tem como objetivo mostrar que Borges convida o leitor a mergulhar, em alguns de seus textos, em conceitos e percepções que estiveram presentes na complexa história da formação da nacionalidade na Região do Prata durante o século XIX. Nessa história, podemos encontrar o debate entre duas visões que prevaleceram na literatura argentina na segunda metade do século retrasado: a "interpretação do atraso" de Domingo Faustino Sarmiento, em seu Facundo o Civilización y Barbarie e a "denúncia da exploração" de José Hernández em seu poema El Gaucho Martin Fierro. Nesse debate, Borges tenta caracterizar o gaucho, um ser assimilado ou desaparecido no processo de consolidação da Nação Argentina. Podemos também encontrar um Borges contraditório. Se por um lado ele defende a civilização, por outro se vê fascinado pelo autêntico: aquele que seria o verdadeiro sul-americano, não necessariamente civilizado na concepção discutida por Sarmiento. Um ser distante das cidades. Enfim, o artigo busca mostrar que Borges, em suas múltiplas faces, foi um escritor político e tratou essa temática de uma forma particular. Apesar das suas críticas ao peronismo, Borges optou por buscar no passado, no século XIX, as causas do que ele definiria como sendo o seu "eu sul-americano", como se quisesse recuperar um momento perdido ou pouco contado e nele encontrar as verdadeiras causas para os problemas ou desvios que a Argentina passaria a enfrentar durante o século XX.

\footnotetext{
${ }^{1}$ BORGES, Jorge Luis. Prólogo, com um prólogo de prólogos (Tradução de Josely Vianna Baptista). São Paulo: Companhia das Letras, [1975] 2010, p. 189. Prólogo escrito por Borges na edição de Facundo, publicado pelo "El Ateneo" Editorial, Libros Fundamentales Comentados, de 1974.
} 
A obra de Borges sobre os temas aqui discutidos é extensa. O presente artigo tem pretensões modestas e se limitou à leitura de alguns dos principais textos do autor. São eles: $A$ poesia gauchesca, de 1932, o Prólogo à edição de Facundo o Civilización y Barbarie, de 1974, o Prólogo à edição de Recuerdos de Provincia, de 1944, o Prólogo à edição do poema El Gaucho Martín Fierro, de 1962, o poema Matín Fierro, de 1960, o poema Os Gauchos, de 1969, o conto Biografia de Tadeo Isidoro Cruz (1829 - 1874), de 1949 e o Poema Conjectural, de 1943. Existe também uma ampla literatura crítica sobre o autor. Não é objetivo deste artigo dialogar com os críticos de Borges. Deixamos apenas como referência dois críticos literários que tratam das questões aqui discutidas: Beatriz Sarlo e Ricardo Piglia.

$\mathrm{O}$ artigo se divide em duas partes. Na primeira, apresenta-se a leitura de Borges sobre um denso debate que ocorreu nas letras argentinas no século XIX: a tese de Sarmiento, com seu Facundo o Civilización y Barbarie e a de Hernández, com o seu poema El Gaucho Martín Fierro. Na segunda parte apresentam-se algumas visões de Borges sobre o gaucho ou, de uma forma mais geral, sobre um ser sul-americano que o autor percebeu existir naquele século. Tratava-se de um ser criado distante das cidades, na periferia, nos pampas da Argentina, ainda sem o contato com o exterior ou com a civilização.

\section{Sarmiento e Hernández}

Borges foi, além de escritor e poeta, um crítico literário. Sua crítica teve alguns destinos e a poesia gauchesca foi um deles. Em seu texto intitulado A poesia gauchesca, publicado originalmente em 1932, examina os sucessivos poetas, de Bartolomé Hidalgo, o iniciador, até José Hernández, aquele que encerra o ciclo de um gênero que Ángel Rama irá considerar décadas mais tarde como sendo "a primeira produção original que conheceram as literaturas do continente americano" ${ }^{2}$.

Muito mais do que as questões literárias, Borges se preocupa, nesse texto, com as origens históricas do fenômeno literário:

[...] Pesquisar as causas de um fenômeno, mesmo de um fenômeno tão simples como a literatura gauchesca, é avançar no infinito; limito-me a mencionar as duas causas que considero principais.

Os que me precederam neste labor restringiram-se a uma: a vida pastoril que era típica das coxilhas e do pampa. Essa causa, sem dúvida apta à amplificação oratória e à digressão pitoresca, é insuficiente; a vida pastoril foi típica de muitas regiões da América, de Montana e Oregon até o Chile, mas esses territórios, até agora,

\footnotetext{
${ }^{2}$ RAMA, Angel. Poesia Politica Gauchesca (Tradução de Adriana Junqueira Arantes). São Paulo: Coleção Memo - Ensaio/Ficção. Fundação Memorial da América Latina, [1976], 2000, p.5.
} 
abstiveram-se energicamente de redigir El gaucho Martín Fierro. Não bastam, pois, o rude pastor e o deserto. O caubói, apesar dos livros documentais de Will Janes e do insistente cinema, pesa menos na literatura de seu país que os camponeses do Middle West ou os homens negros do Sul... Derivar a literatura gauchesca de sua matéria, o gaucho, é um engano que desfigura a notória verdade. Não menos necessário para a formação desse gênero do que o pampa e as coxilhas foi o caráter urbano de Buenos Aires e Montevidéu. As guerras da Independência, a guerra do Brasil, as guerras anárquicas fizeram com que homens de cultura civil se identificassem com a gaucharia; da fortuita conjunção desses dois estilos vitais, do assombro que um causou no outro, nasceu a literatura gauchesca. ${ }^{3}$

Borges percebeu, já na década de 30 do século passado, que a literatura gauchesca não era a voz do gaucho, ainda que afirmasse que "Tachar a literatura gauchesca de artificial ou de inverídica por não ser obra de gauchos é pedante e ridículo". ${ }^{4}$ Percebeu o fato de ter sido uma literatura escrita pelos homens da cidade e com motivações políticas, carregadas de histórias de conflitos, com denúncias e que, na visão do autor, era produzida muitas vezes por interesses oportunistas, como no caso do poema de José Hernández. O conflito seria aquele que nortearia a formação da nacionalidade argentina durante todo o século XIX: a luta entre o campo e a cidade, entre o gaucho do pampa (e depois o índio da fronteira) e o americano de influência cultural européia da cidade. No campo político, os conflitos se dariam entre o Partido Federal, representante das províncias e o Partido Unitário, representante dos interesses da cidade de Buenos Aires.

O conflito entre o campo e a cidade na Região do Prata foi também é sugerido nas letras argentinas por Domingo Faustino Sarmiento em seu famoso livro Facundo o Civilización y Barbarie, publicado originalmente em 1845. Nessa obra, Sarmiento, inspirado por Alexis de Tocqueville e outros da sua época, se utiliza da biografia do caudilho Juan Facundo Quiroga para criticar o atraso da Argentina dos caudilhos das províncias do interior da Argentina, que dominavam a frágil nação. Quiroga e tantos outros representavam, para Sarmiento, a barbárie em um país que teria grande potencial para alcançar o progresso material, a civilização. Tratava-se também de uma denúncia política: os malefícios da ditadura do caudilho Juan Manuel de Rosas, representante do Partido Federal e que ocupava o poder quando a obra Facundo foi concebida. Sarmiento se revelava contra as práticas políticas dos caudilhos do interior, ainda que, na interpretação de alguns historiadores, muitos

\footnotetext{
${ }^{3}$ BORGES, Jorge Luis. Discussão (Tradução de Josely Vianna Baptista). São Paulo: Companhia das Letras, [1932] 2002, p. $11-12$.

${ }^{4}$ BORGES, Jorge Luis. Discussão (Tradução de Josely Vianna Baptista). São Paulo: Companhia das Letras, [1932] 2002, p. $11-12$.
} 
eles teriam sido autênticos representantes das aspirações populares. ${ }^{5}$ Havia também uma tentativa de interpretação do atraso argentino a partir da percepção da existência de uma sociedade rural com traços feudais ou pré-capitalistas:

\begin{abstract}
Nas planícies argentinas não existe a tribo nômade: o pastor possui o solo com títulos de propriedade; está fixo num ponto, que lhe pertence; mas para ocupá-lo, foi preciso dissolver a associação e derramar as famílias sobre uma imensa superfície. Imaginem uma extensão de 2 mil léguas quadradas, toda coberta de população, mas com as habitações situadas a quatro léguas de distância uma das outras, ou até oito, às vezes; as mais próximas duas. O desenvolvimento da propriedade mobiliária não é impossível; os confortos do luxo não são de todo incompatíveis com esse isolamento: a fortuna pode levantar um soberbo edifício no deserto; mas falta o estímulo, desaparece o exemplo; a necessidade de se apresentar com dignidade, que é sentida nas cidades, não se faz sentir ali, no isolamento e na soledade. As privações indispensáveis justificam a preguiça natural, e a frugalidade dos confortos traz, em seguida, todas as exterioridades da barbárie. A sociedade então desapareceu completamente; fica só a família feudal, isolada, concentrada; e não havendo sociedade reunida, toda forma de governo se torna impossível: a municipalidade não existe, a polícia não pode ser exercida e a justiça civil não tem meios de atingir os delinquentes. ${ }^{6}$
\end{abstract}

A denúncia de Sarmiento parecia refletir a disparidade entre a Argentina de Rosas, que comandava a Região do Prata a partir da cidade de Buenos Aires (e com as receitas do porto), e as possibilidades criadas pela revolução industrial que se podia observar a partir da Europa. Enquanto a cidade de Buenos Aires permanecia estagnada, com os traços bárbaros do campo semi-feudal, multiplicavam-se na Europa as possibilidades como a do uso das ferrovias, dos telégrafos, do vapor como fonte de energia e das várias tecnologias que o progresso humano permitia criar. Ou seja, Sarmiento via o setor rural argentino sinônimo de atraso e ao mesmo tempo percebia a vida nas cidades um meio de progresso econômico e, de certa forma, social.

No prólogo à edição de Facundo de 1974, Borges parece reafirmar a interpretação de Sarmiento e adotar a posição da civilização:

O Facundo propõe-nos uma alternativa - civilização ou barbárie - que é aplicável, a meu ver, ao processo cabal de nossa história. Para Sarmiento, a barbárie era a planície das tribos aborígenes e do gaucho; a civilização, as cidades. O gaucho foi substituído por colonos e operários; a barbárie não está apenas no campo, mas na plebe das grandes cidades, e o demagogo cumpre a função do antigo caudilho, que

\footnotetext{
${ }^{5}$ Essa é uma das hipóteses de SHUMWAY, Nicolas. A Invenção da Argentina: a história de uma ideia. São Paulo/ Brasília: Editora Edusp/Editora UNB, [1991] 2008. Neste livro, Shumway destaca o caudilho José Artigas, dentre outros.

${ }^{6}$ Sarmiento, Domingo Faustino. Facundo ou Civilização e Barbárie (Tradução: Sérgio Alcides). São Paulo: Editora Cosacnaify, 2010, p. 86-87.
} 
também era um demagogo. Sub specie aeternitatis, o Facundo é ainda a melhor história argentina. ${ }^{7}$

Nesse prólogo, como em outros textos sobre a literatura argentina do século XIX, Borges vai além dos aspectos literários. Penetra em polêmicas questões históricas referentes ao conflito entre as províncias do interior e a cidade de Buenos Aires. Também julga o caudilho e ditador Juan Manuel de Rosas (o antigo caudilho), que exerceu seu poder sobre a Argentina entre 1829 e 1852. Mas mais do que isso. Busca transportar a demagogia do ditador, o demagogo, para uma época futura, para a época em que se viu em conflito com o peronismo.

Em outro prólogo, destinado ao livro Recuerdos de Provincia, um ensaio autobiográfico e também um dos principais livros de Sarmiento, publicado originalmente em 1850, Borges considera:

\begin{abstract}
Nenhum espectador argentino tem a clarividência de Sarmiento. Sobre o que foi a conquista desta parte da América: fragmentária e lentíssima ocupação de quase desertas planícies. Sabe que a revolução, em troca de emancipar todo o continente e de alcançar vitórias no Peru e no Chile, abandonou, ainda que transitoriamente, o país às forças da ambição pessoal e da rotina. Sabe que nosso patrimônio não deve ser reduzido ao haveres do índio, do gaucho e do espanhol; que podemos aspirar à plenitude da cultura ocidental, sem exclusão alguma. ${ }^{8}$
\end{abstract}

Ou seja, para Borges, como para Sarmiento, o processo civilizatório deveria ser conduzido a partir da assimilação, pelo nosso americano, da cultura européia e depois do modelo norte-americano que Sarmiento descobrira em suas viagens pelo norte do novo continente.

Finalmente a ditadura de Juan Manuel de Rosas cai em 1852. A partir de então cada vez mais o Partido Unitário e Elites da província de Buenos Aires passam a prevalecer sobre as províncias do interior, mas não sem conflitos. Após a queda de Rosas, a Argentina se divide em duas: de um lado Buenos Aires, liderada por Bartolomé Mitre, representante do Partido Unitário e defensor dos interesses do porto (e suas receitas aduaneiras) e do outro as treze províncias lideradas pelo caudilho Justo José Urquiza, representante do Partido Federal. A região mergulha então em uma grande guerra civil. Logo depois tem início a Guerra do Paraguai. Sarmiento, personalidade que sempre se identificou com a política e esteve próxima

\footnotetext{
${ }^{7}$ BORGES, Jorge Luis. Prólogo, com um prólogo de prólogos (Tradução de Josely Vianna Baptista). São Paulo: Companhia das Letras, [1975] 2010, p. 182. Esse prólogo foi publicado na edição de Facundo de El Ateneo Editorial, Libros Fundamentales Comentados, em 1974.

${ }^{8}$ BORGES, Jorge Luis. Prólogo, com um prólogo de prólogos (Tradução de Josely Vianna Baptista). São Paulo: Companhia das Letras, [1975] 2010, p. 180. Prólogo da Edição de Recuedos de Provincia, publicado pela Emecé, Colección El Navio, em 1944.
} 
ao Partido Unitário, assume a presidência em 1868. Em 1872 surge o poema El Gaucho Martin Fierro. Nesse poema, Hernández conta as desventuras do pobre gaucho Martin Fierro, que é recrutado pelas forças do exército do governo argentino para lutar contra os índios em terras ainda não conquistadas: ${ }^{9}$

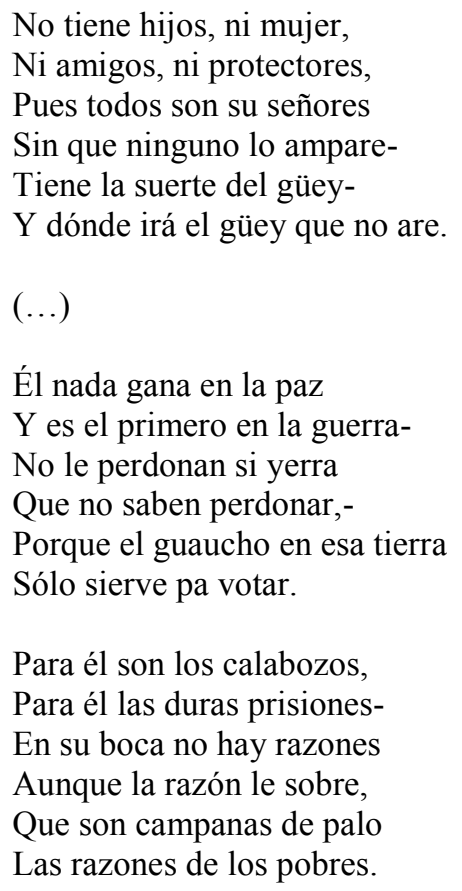

Com esse poema, José Hernandez apresentaria uma interpretação completamente diferente daquela defendida por Sarmiento: o gaucho não era bárbaro, mas um autêntico latino-americano, um ser oprimido e manipulado.

Borges realizou três prólogos para a obra de El Gaucho Martín Fierro e tal produção sugere certo fascínio por esse poema. ${ }^{10}$ Como nos prólogos realizadas para as obras de Sarmiento, não se contentou com as questões literárias. Procurou julgar Hernández pela sua condição de simpatizante do Partido Federal. "Hernández era federalista, e as melhores pessoas do país abominavam, por motivos morais e intelectuais, esse partido. Em uma cidade onde todos se conheciam, Hernández quase não deixou uma história." ${ }^{11}$ No mesmo prólogo, afirmou:

\footnotetext{
${ }^{9}$ HERNÁNDEZ, José. Martín Fierro. Barcelona: Barcelona: Colección Archivos/Scipione. [1872] 2001, p. 163 $-164$.

${ }^{10}$ Os prólogos foram para as edições de: Buenos Aires: Editorial Sur, 1962; Edição fac-similar - Buenos Aires: Ediciones Centurión, 1962; e a de Buenos Aires: Santiago Rueda Editor, 1968. Borges publica ainda, em 1953, El Martin Fierro, em co-autoria com Margarita Guerrero. Existe uma tradução desse livro para o português: BORGES, Jorge Luis. O “Martín Fierro” (Tradução de Carmem Vera Cirne Lima). São Paulo: L\&PM, 2007.

${ }^{11}$ BORGES, Jorge Luis. Prólogo, com um prólogo de prólogos (Tradução de Josely Vianna Baptista). São Paulo: Companhia das Letras, [1975] 2010, p. 119. Prólogo da Edição de Martín Fierro publicado pelo Editorial Sur, em 1962.
} 
O propósito do autor não era literário, mas político, e assim o entenderam seus contemporâneos, cuja cegueira crítica não devemos nos apressar a condenar. Hernández, homem de tradição federalista, queria demonstrar, entre outras coisas, que a batalha de Caseros, ocorrida vinte anos antes, não havia melhorado a pobre sorte dos gauchos. A defesa da fronteira contra os índios transformara o exército em um estabelecimento penal, alimentado pelos cárceres e pela prática ilegal de levas arbitrárias. Hernández queria denunciar tais abusos e não encontrou, felizmente para nós, melhor meio para nós que o verso. Devia pensar, também, que Estanislao del Campo e Ascasubi haviam falseado, exagerando-a, a genuína linguagem dos gauchos; de tudo isso, surgiu o propósito de um poema no qual um gaucho cantaria, com autêntica voz, as desventuras e misérias a que o governo o submetera. Esse gaucho devia ser genérico, para que todos pudessem identificar-se com eles; por isso, Martín Fierro não tem pais conhecidos (...). ${ }^{12}$

$\mathrm{Na}$ verdade Borges viu o que outros perceberiam mais tarde: que a literatura gauchesca de Hernández tinha algo além de literária. Era em grande parte política. José Hernandez, além de escritor, era jornalista e opositor ao Partido Unitário. Quando o poema foi concebido, Buenos Aires e o Partido Unitário prevaleciam sobre as demais províncias com a força do seu exército mantido pela receitas aduaneiras do porto e pela sua capacidade de tomar empréstimos junto ao exterior. Sarmiento era presidente e o Paraguai era sufocado por uma guerra impopular em vários setores da sociedade na Região do Prata. Buenos Aires seguia com o seu dinamismo econômico, enquanto o interior sofria com a escassez de recursos. Muitas vozes tentaram denunciar essa situação. A voz de José Hernández foi uma delas. $^{13}$ Borges considerou essa denúncia como uma visão distorcida e oportunista. Interessante notar que Borges, em várias ocasiões, se mostrou avesso à política. Tratava-se de uma postura contraditória, considerando a sua leitura do passado. ${ }^{14}$

A despeito da popularidade que o poema de Hernández alcançou entre a população do campo logo após o seu lançamento, foi praticamente ignorado entre os escritores e leitores intelectuais de Buenos Aires. ${ }^{15} \mathrm{O}$ reconhecimento somente começou a aparecer com os elogios aceitos pela elite portenha, como aqueles encontrados no texto El Payador, do escritor Leopoldo Lugones, publicado originalmente em 1916. Nele, Lugones considera El Gaucho

\footnotetext{
${ }^{12}$ BORGES, Jorge Luis. Prólogo, com um prólogo de prólogos (Tradução de Josely Vianna Baptista). São Paulo:Companhia das Letras, [1975] 2010, p. 125. Prólogo da Edição de Martín Fierro publicado pelo Editorial Sur, em 1962 .

${ }^{13}$ Além de Hernández, Juan Bautista Alberdi, contemporâneo de Sarmiento, foi outro intelectual argentino a denunciar a situação em várias de suas obras. Na historiografia contemporânea, o texto de SHUMWAY, citado neste artigo, defende os argumentos aqui colocados e apresenta uma ampla bibliografia sobre o assunto.

${ }^{14}$ Uma dessas opiniões a respeito da sua aversão à política pode ser encontrada nas entrevistas que concedeu a Osvaldo Ferrari (BORGES, Jorge Luis e Osvaldo Ferrari. Sobre a filosofia e outros diálogos - Tradução de John O'Kuinghttons. São Paulo: Editora Hedra Ltda, [1985] 2009, p. 165).

${ }^{15}$ SHUMWAY, Nicolas. A Invenção da Argentina: a história de uma ideia. São Paulo/ Brasília: Editora Edusp/Editora UNB, [1991] 2008, p. 351.
} 
Martin Fierro como a grande obra épica nacional. Tal classificação causou certa indignação em Borges que, em resposta, publica, em 1960, o poema Martín Fierro:

Desta cidade saíram exércitos que pareciam grandes e que depois o foram pela magnificação da glória. Anos depois, um dos soldados voltou e, com sotaque forasteiro, contou histórias que lhe haviam sucedido em lugares chamados Ituzaingó ou Ayacucho. Essas coisas, agora, são como se não tivessem sido. Houve aqui duas tiranias. Durante a primeira, alguns homens, da boléia de uma carroça que saía do mercado do Prata, apregoaram pêssegos brancos e amarelos; um menino levantou uma ponta da lona que os cobria e viu cabeças unitárias com a barba ensangüentada. A segunda foi para muitos cárcere e morte; para todos um mal-estar, um gosto de opróbrio nos atos de cada dia, uma humilhação incessante. Essas coisas, agora, são como se não tivesse sido. Um homem que sabia todas as palavras olhou com minucioso amor as plantas e os pássaros desta terra e is definiu, talvez para sempre, e escreveu com metáforas de metais a vasta crônica dos tumultuosos poentes e das formas da lua. Essas coisas, agora, são como se não tivessem sido. Também aqui as gerações conheceram essas vicissitudes comuns e de certo modo eternas que são a matéria da arte. Essas coisas, agora, são como se não tivessem sido, mas num quarto de hotel, pelos anos de mil oitocentos e sessenta e tantos, um homem sonhou uma peleja. Um gaúcho levanta um negro com a faca, arremessa-o como se fosse um saco de ossos, vê-o agonizar e morrer, agacha-se para limpar o aço, desamarra seu cavalo e monta devagar, para que não pensem que está fugindo. O que aconteceu uma vez volta a acontecer, infinitamente; os visíveis exércitos se foram e resta um pobre duelo de facas; o sonho de um é parte da memória de todos. ${ }^{16}$

Ou seja, o épico, o perfeito, não era mais do que um sonho moralmente imperfeito. ${ }^{17}$ Borges parecia não se conformar com a imperfeição e simplicidade do caráter de Fierro. Também não se conformava com a repercussão do poema.

\section{O gaucho: o ser sul-americano}

Havia, entretanto, um gaucho que fascinava Borges. O poema Os gauchos, escrito originalmente em 1969, permite algumas pistas sobre essa hipótese. Nesse poema, Borges tenta dar algum sentido ao ser estranho, descrevendo-o e de certa forma redimindo-o:

Quem lhes teria dito que seus antepassados vieram por um mar, que lhes teria dito o que são um mar e suas águas.

(...)

Foram pastores do gado bravio, firmes no cavalo do deserto que haviam domado de manhã, laçadores, marcadores, tropeiros, homens do bando policial, vez por outra matreiros; um deles, o escutado, foi o cantador.

(...)

\footnotetext{
${ }^{16}$ BORGES, Jorge Luis. O Fazedor (Tradução de Josely Vianna Baptista). São Paulo: Companhia das Letras, [1960] 2008, p. 37 - 38.

${ }^{17}$ Para uma interpretação desse poema, ver SARLO, Beatriz. Jorge Luis Borges: um escritor na periferia (tradução Samuel Titan Jr.). São Paulo: Iluminuras, [1993] 2008. Para essa autora, Borges trata o Poema de Hernández como uma novela mal acabada. A interpretação aqui considerada segue a interpretação da autora.
} 
Ao contrário de outros camponeses, eram capazes de ironia.

Eram sofridos, castos e pobres. A hospitalidade foi sua festa.

Alguma noite perdeu-os o encrenqueiro álcool dos sábado.

Morriam e matavam com inocência.

Não eram devotos, salvo alguma obscura superstição, mas a vida dura ensinou-lhes o culto da coragem.

Homens da cidade fabricaram um dialeto e uma poesia de metáforas rústicas.

Certamente não foram aventureiros, mas uma tropa os levavam muito longe, e ainda mais longe as guerras.

Não deram à história um só caudilho. Foram homens de Lópes, de Ramírez, de Artigas, de Quiroga, de Bustos, de Pedro Campbell, de Rosas, de Urquiza, daquele Ricardo López Jordán que mandou matar Urquiza, de Peñaloza e de Saraiva.

Não morreram por essa coisa abstrata, a pátria, mas por um patrão casual, uma ira ou pela incitação a um perigo (...). ${ }^{18}$

Ou seja, na interpretação de Borges, esses americanos desaparecidos, ou assimilados, ou civilizados, ou exterminados, não morreram pela pátria, mas foram manipulados por homens oportunistas: os caudilhos; e talvez essa seja a indignação do autor pela poesia de Hernández. Borges, em seu Ensaio Autobiográfico, destacou ter sido de origem de uma família simpatizante e militante do Partido Unitário e talvez por isso aprendeu a alimentar aversão aos caudilhos, particularmente Juan Manuel de Rosas. ${ }^{19}$ Também argumentou, no prólogo realizado para a edição de Facundo que os "caudilhos foram hostis à causa da América. Viram, ou quiseram ver, um pretexto de Buenos Aires para dominar as províncias". ${ }^{20}$ Procurou, entretanto, separar os caudilhos dos gauchos e essa separação permitiu-o cultivar certa fascinação por esse ser bárbaro, inferior, porém autêntico. Tratava-se de um ser criado longe da cidade de Buenos Aires, longe da influência européia, do capitalismo mercantil do porto. Essa fascinação, ou perplexidade, consciente ou não, pode ser lida em algumas histórias que Borges tenta criar sobre a vida gaucho. Mas não qualquer um. Escolhe aquele que foi companheiro de aventura de Martín Fierro. No livro O Aleph,

\footnotetext{
${ }^{18}$ BORGES, Jorge Luis. Poesia (Tradução de Josely Vianna Baptista). São Paulo: Companhia das Letras, 2009, p. 55 - 56. O referido livro é uma coletânea de poesia de Borges. O poema faz parte do livro Elogia da sombra, publicado originalmente em 1969.

${ }^{19}$ BORGES, Jorge Luis. Ensaio Autobiográfico (1899 - 1870) (Tradução de Maria Carolina de Araujo e Jorge Schwatz). São Paulo: Companhia das Letras, [1970] 2009. A descrição do seu passado e origem política do autor está descrita no capítulo 1 desse livro.

20 BORGES, Jorge Luis. Prólogo, com um prólogo de prólogos (Tradução de Josely Vianna Baptista). São Paulo: Companhia das Letras, [1975] 2010, p. 188. Prólogo de Facundo, publicado "El Ateneo" Editorial, Libros Fundamentales Comentados, em 1974.
} 
publicado originalmente em 1949, Borges cria o conto intitulado Biografia de Tadeo Isidoro Cruz (1829 - 1874), em que narra a história do companheiro Cruz, de Martin Fierro:

\begin{abstract}
Os que comentaram, e são muitos, a história de Tadeo Isidoro Cruz destacam a influência da planície sobre sua formação, mas gauchos idênticos a eles nasceram e morreram nas ribeiras selvagens do Paraná e nas coxilhas Uruguaias. Viveu, isso sim, num mundo de barbárie monótona. Quando, em 1874, morreu de uma varíola maligna, nunca vira uma montanha nem um bico de gás nem um moinho. Tampouco uma cidade. Em 1849, foi a Buenos Aires com uma tropa da propriedade de Francisco Xavier Acevedo; os tropeiros entraram na cidade para esvaziar os bolsos; Cruz, receoso, não saiu de uma pousada na vizinhança dos currais. Ali passou muitos dias, taciturno, dormindo no chão, mateando, levantando ao alvorecer e se recolhendo à noitinha. Compreendeu (além das palavras e mesmo do entendimento) que a cidade nada tinha a ver com ele. ${ }^{21}$
\end{abstract}

Fica mais uma vez evidente a dicotomia ou o conflito cidade versus campo, tal qual aquela descrita por Sarmiento, ou seja, a civilização e a barbárie, mas não de forma agressiva, pois nessa história não se trata de um caudilho e sim de um soldado. Mais interessante é o momento da transformação de Tadeu Isidoro Cruz. Mais interessante é o momento em que Cruz se identifica com Martín Fierro. Era o momento da consolidação do poder da cidade de Buenos Aires e da Argentina como Nação. Foi o momento em que Cruz, soldado encarregado de capturar Fierro, se identifica com este personagem e muda de posição:

\begin{abstract}
O criminoso saiu do abrigo para lutar com eles. Cruz o entreviu, terrível; a cabeleira crescida e a barba cinza pareciam comer seu rosto. Um motivo notório me impede de relatar a luta. Basta lembrar que o desertor feriu de morte ou matou vários dos homens de Cruz. Este, enquanto combatia na escuridão (enquanto seu corpo combatia na escuridão), começou a compreender. Compreendeu que um destino não é melhor que outro, mas que todo homem deve acatar o que traz dentro de si. Compreendeu que as divisas e o uniforme o estorvavam. Compreendeu seu íntimo destino de lobo, não de cão gregário; compreendeu que o outro era ele. Amanhecia na planície desmesurada; Cruz jogou no chão o quepe, gritou que não ia consentir o crime de que matassem um valente e se pôs a lutar contra os soldados, junto do desertor Martín Fierro. ${ }^{22}$
\end{abstract}

Qual seria essa descoberta por parte de Cruz? Ser lobo e não um cão gregário; não ter as divisas e o uniforme de militar, ou seja, não lutar nas guerras escolhidas pelo Partido Unitário. Não servir às tropas que, naquele momento, estavam vinculadas aos interesses da cidade de Buenos Aires. Ser um autêntico sul-americano, com todas as suas imperfeições. Sim, imperfeições que Borges reconheceria no Poema Conjectural, escrito originalmente em 1943. Nesse poema, Borges toma as palavras do personagem Narciso de Laprida (1786 -

\footnotetext{
${ }^{21}$ BORGES, Jorge Luis. O Aleph (Tradução de Davi Arrigucci Jr). São Paulo: Companhia das Letras, [1949] 2010, p. 50.

${ }^{22}$ BORGES, Jorge Luis. O Aleph (Tradução de Davi Arrigucci Jr). São Paulo: Companhia das Letras, [1949] 2010, p. 52.
} 
1829), deputado pela Província de San Juan frente ao Congresso de Tucumán e que assinou, em caráter de presidente da assembléia, a ata da declaração da independência das Províncias Unidas do Rio da Prata em 1816 e que teria sido morto pelos montoneros do Caudilho José Felix Aldao. Seriam as palavras de Laprida na hora de sua morte:

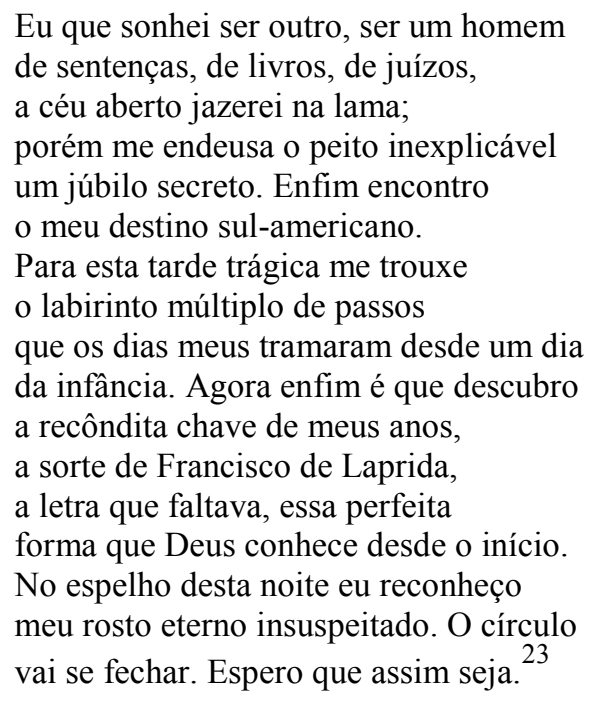

Nesse poema pode-se ler uma das frases mais impactantes de Borges: "Enfim encontro o meu destino sul-americano". Estaria Borges condenando o seu ser autêntico? Estaria ele frustrado pela Argentina não ter conseguido criar, em sua totalidade, homens de livros, "civilizados", das cidades e de uma cultura semelhante àquela encontrada na Europa? Ou mais uma vez, como na história Tadeo Isidoro Cruz, deveria a Argentina ter seguido o seu caminho, o seu encontro com o seu verdadeiro destino americano, algo autêntico, ainda que distante da civilização idealizada pelos homens da cidade de Buenos Aires? Para o bem ou para o mal, esse ser teria desaparecido. Teria sido exterminado ou assimilado pela cidade e pelo processo migratório que se iniciaria a partir do final do século XIX. Estaria Borges sugerindo um destino mal concebido para o seu país, ditado pelo mercantilismo do porto, cujos interesses eram o comércio e a prosperidade de um capitalismo que teimaria não dar certo na Argentina ao longo de sua história? Borges pouco desenvolve essa ideia. Toda sua indignação política é canalizada contra o peronismo, que lhe foi hostil em seu pensamento. Porém ao tratar de algumas questões presentes formação da nacionalidade da Argentina do século XIX, deixou várias perguntas a serem respondidas, como um convite: é possível entender a Argentina atual a partir dos seus erros ou acertos no passado? Se Borges sugere

\footnotetext{
${ }^{23}$ BORGES, Jorge Luis. O outro, o mesmo (Tradução Heloisa Jahn). São Paulo: Companhia das Letras, [1964], 2009 , p. 35.
} 
uma resposta ao escolher Facundo ou a civilização de Sarmiento, cria uma simpatia pelo oposto.

\section{Considerações Finais}

Borges, apesar da opção revelada pela civilização, parece ter alimentado grande fascínio por determinados aspectos da barbárie. Na verdade tratava-se de um fascínio pelos gaúchos. Como se houvesse algo a ser desvendado nesse ser. Poderia ser o gaucho descrito na história de Hernández, mas essa descrição era incompleta. Precisava ser recontada. ${ }^{24}$ Mas esse gaucho não mais existia quando Borges começou a escrever. Tratava-se apenas de lembranças, invenções ou repetições de histórias contadas por outros. O gaucho já teria sido assimilado ou civilizado pelos livros, batalhas, modelos ou decisões impostas por aqueles que detinham o poder em uma época de grandes conflitos na Região do Prata. O livro de Sarmiento, ao contrário do que Borges sugere, já teria sido canonizado. A Argentina teria optado pela cidade, pela civilização, pela imigração, pelas ideias européias, pelo fim dos gauchos, pelo liberalismo econômico ditado pelo porto, ainda que houvesse outras opções, como aquelas propostas por Juan Bautista Alberdi, autor esquecido por Borges. ${ }^{25}$

Apesar dos seus conflitos com o peronismo, Borges evitou escrever sobre a política argentina do século XX. Em vez disso, escolheu o século XIX como palco político para várias de suas criações, como se buscasse naquele período as respostas para a existência de um país em permanente conflito ideológico, marcado por golpes militares, por crises econômicas, pelo populismo e pela violência. Em alguns textos, talvez possamos ler uma tentativa de relacionar aquele momento histórico com os que o autor viveu ao longo de sua vida. Talvez esse seja o caso da sua interpretação acerca da relação entre o populismo do antigo e do "novo caudilho", sugerido no prólogo realizado para a edição de Facundo em 1974, concebido exatamente no momento em que Perón retorna ao na Argentina.

\footnotetext{
${ }^{24}$ Essa interpretação é discutida de forma densa em PIGLIA, Ricardo. Crítica y ficción. Barcelona: Editorial Anagrama, [1996], 2001, p. 151.

25 Juan Bautista Alberdi (1810-1884) fez parte de uma geração de escritores e militantes políticos que contribuíram, junto com Sarmiento, para a saída de Juan Manuel de Rosas do Poder. Depois passou a criticar Sarmiento por perceber que o processo civilizatório proposto pelo antigo aliado não era de inclusão, mas de exclusão dos caudilhos, dos gauchos e do interior da Argentina. Também foi contra a Guerra do Paraguai, denunciando-a como conflitos motivados por interesses políticos de poucos em detrimento de muitos. Essa leitura pode ser encontrada em ALBERDI, Juan Bautista. Estudios Póstumos, Tomo I. Buenos Aires: Universidad Nacional de Quilmes, 1993.
} 
Em um dos livros mais interessantes sobre o pensamento de Borges, escrito originalmente em 1993, Beatriz Sarlo, escritora e crítica literária argentina, defende uma hipótese sobre Borges:

\begin{abstract}
Por ali estava, ainda muito próximo de Borges, o século XIX rio-pratense, a literatura gauchesca, os escritores de Sarmiento, a saga familiar das guerras civis que precederam a organização do estado nacional, as lutas de índios e brancos durante décadas implacáveis, sangrentas e injustas. Esses traços do passado nacional argentino não desapareceram nunca na obra de Borges; ao contrário, sua literatura cumpre, entre outras tarefas, a de voltar a juntar os fragmentos dispersos e rearticular a escrita própria com a de outros argentinos mortos. ${ }^{26}$
\end{abstract}

Essa característica levou o escritor e crítico literário Ricardo Piglia, por meio do seu personagem Emilio Renzi, a definir Borges como sendo o melhor escritor argentino do século $X I X{ }^{27} \mathrm{Ou}$ seja, Borges talvez mais do que qualquer outro, mistura ficção e realidade.

Mas para quem Borges escrevia quando tratava da Argentina? Estaria tentando mostrar de forma não tão sutil uma crítica ao peronismo? Estaria destinando os seus textos ao leitor argentino? Estaria, como escritor universal, tentando mostrar ao mundo a riqueza em torno do debate sobre a "invenção da Argentina"? Ou estaria, não simplesmente, mantendo uma tradição entre os escritores de seu país, de misturar ficção, literatura, história e política? São perguntas para serem respondidas pelo leitor. O mais importante talvez seja o método: podemos usar a literatura, e não qualquer literatura (como afirma Emilio Renzi), para entender um pouco mais acerca da nossa história.

Em relação às possíveis contradições em torno das idéias de Borges, merece destaque em texto publicado originalmente em 1960, em que o autor fala da sua contradição: "Eu permanecerei em Borges, não em mim (se é que sou alguém), mas me reconheço menos em seus livros do que em muitos outros, ou do que no laborioso rasqueado de uma guitarra". ${ }^{28}$

\title{
Referências
}

ALBERDI, Juan Bautista. Escritos póstumos de J. B. Alberdi - tomo I. Buenos Aires: Universidad Nacional de Quilmes, 1996, 441 p.

BORGES, Jorge Luis. Discussão. São Paulo: Companhia das Letras, 2002. 176 p. O Fazedor. São Paulo: Companhia das Letras, 2008. 168 p.

\footnotetext{
${ }^{26}$ SARLO, Beatriz. Jorge Luis Borges: um escritor na periferia (tradução Samuel Titan Jr.). São Paulo: Iluminuras, [1993] 2008, p. 18.

${ }^{27}$ Piglia, Ricardo. Respiração Artificial (Tradução Heloisa Jahn). São Paulo: Editora Iluminuras, 2008, p. 122.

${ }^{28}$ BORGES, Jorge Luis. O Fazedor (Tradução de Josely Vianna Baptista). São Paulo: Companhia das Letras, [1960] 2008, p. 55.
} 
. Ensaio Autobiográfico (1899 - 1870). São Paulo: Companhia das Letras, 2009. 83 p.

. O outro, o mesmo. São Paulo: Companhia das Letras, 2009. 227 p.

. Poesia. São Paulo: Editora Companhia das Letras, 2009.641 p.

O Aleph. São Paulo: Companhia das Letras, 2010. 156 p.

2010. 238p.

Prólogo, com um prólogo de prólogos. São Paulo: Editora Companhia das Letras,

BORGES, Jorge Luis; GUERRERO, Margarita. O "Marín Fierro". Porto Alegre: L\&MP, 2007. 98 p.

BORGES, Jorge Luis; FERRARI, Osvaldo . Sobre a filosofia e outros diálogos. Tradução de John O'Kuinghttons. São Paulo: Editora Hedra Ltda, 2009. 249 p.

HERNÁNDEZ, José. Martín Fierro. Barcelona: Colección Archivos/Scipione, 2001. 1429 p.

PIGLIA, Ricardo. Crítica y ficción. Barcelona: Barcelona: Anagrama, 2001. 227 p.

. Respiração Artificial. São Paulo: Iluminuras, 2008. 206 p.

RAMA, Angel. Poesia Política Gauchesca. Tradução de Adriana Junqueira Arantes. São

Paulo: Coleção Memo - Ensaio/Ficção. Fundação Memorial da América Latina, 2000, 18 p.

SARLO, Beatriz. Jorge Luis Borges: um escritor na periferia. São Paulo: Iluminuras, 2009. $157 \mathrm{p}$.

SARMIENTO, Domingo Faustino. Facundo ou Civilização e Barbárie. São Paulo: Cosacnaify, 2010. 508 p.

SHUMWAY, Nicolas. A Invenção da Argentina: a história de uma ideia. São Paulo/Brasília: Editora Edusp/Editora UNB, 2008.

[Recebido em junho de 2011 e aceito para publicação em outubro de 2011]

\section{Gauchos and barbarians: the history of the formation of Argentine nationality from the reading of Jorge Luis Borges}

Abstract: This article aims to show that Borges invites the reader to dive in some of his texts in a complex and compelling history about the birth of the nation in the Region of the Prata during the nineteenth century. In this history, we find the debate between two views that prevailed in Argentine literature in the second half of last century: the "interpretation of barbarism" of Domingo Faustino Sarmiento in his Facundo or Civilización y Barbarie and the "denunciation of the exploration" of José Hernández in his poem El Gaucho Martin Fierro. In this debate, Borges tries to characterize the gaucho, who had been assimilated or 
disappeared in the process of consolidation of the city of Buenos Aires as political and economic center of the region. We also find a contradictory Borges. If from one point of view he defends civilization, from another he finds himself fascinated by the authentic, an inhabitant of this land that is not necessarily a civilized one. Would be Borges most concerned with showing his contradictions? This is perhaps a minor question. More important in his work is the method, that combines history and literature.

Keywords: Jorge Luis Borges. Argentina History. Latin American History.

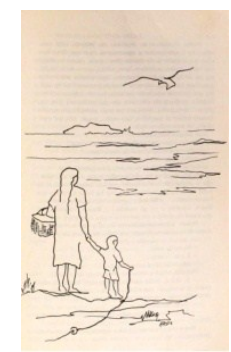

